\title{
Biomass Yield and Nutrient Removal Rates of Perennial Grasses under Nitrogen Fertilization
}

\author{
M. K. Kering • T. J. Butler • J. T. Biermacher • \\ J. A. Guretzky
}

Published online: 25 November 2011

(C) The Author(s) 2011. This article is published with open access at Springerlink.com

\begin{abstract}
Perennial grasses may provide a renewable source of biomass for energy production. Biomass yield, nutrient concentrations, and nutrient removal rates of switchgrass (Panicum virgatum L.), giant miscanthus (Miscanthus x giganteus), giant reed (Arundo donax L.), weeping lovegrass [Eragrostis curvula (Shrad.) Nees], kleingrass (Panicum coloratum L.), and Johnsongrass (Sorghum halepense (L.) Pers.) were evaluated at four N fertilizer rates $\left(0,56,112\right.$, or $\left.168 \mathrm{~kg} \mathrm{Nha}^{-1}\right)$ on a Minco fine sandy loam soil in southern Oklahoma. Species were established in 2008 and harvested for biomass in winter of 2009 and 2010. Biomass yield (dry matter basis) did not show a strong relationship with $\mathrm{N}$ fertilizer rate $(p=0.08)$, but was affected by year and species interactions $(p<0.01)$. Weeping lovegrass and kleingrass produced 29.0 and 16.0 Mg ha $\mathrm{Mg}^{-1}$ in 2009 , but only $13.0 \mathrm{Mg} \mathrm{ha}^{-1}$ and $9.8 \mathrm{Mg} \mathrm{ha}^{-1}$ in 2010 , respectively. Biomass yields of giant reed, switchgrass, and Johnsongrass averaged 23.3, 17.8, and $6.0 \mathrm{Mg} \mathrm{ha}^{-1}$, respectively. Giant miscanthus established poorly, producing only $4.7 \mathrm{Mg} \mathrm{ha}^{-1}$. Across years, giant reed had the highest biomass yield, $33.2 \mathrm{Mg}^{-1}$ at $168 \mathrm{~kg} \mathrm{Nha}^{-1}$, and the highest nutrient concentrations and removal rates (162 to $228 \mathrm{~kg} \mathrm{Nha}^{-1}, 23$ to $25 \mathrm{~kg} \mathrm{Pha}^{-1}$, and 121 to $149 \mathrm{~kg} \mathrm{Kha}^{-1}$ ) among the grasses. Although giant reed demonstrated tremendous biomass production, its
\end{abstract}

\footnotetext{
M. K. Kering $(\bowtie) \cdot$ T. J. Butler $\cdot$ J. T. Biermacher

The Samuel Roberts Noble Foundation,

2510 Sam Noble Parkway,

Ardmore, OK 73401, USA

e-mail: mkkering@noble.org

J. A. Guretzky

Department of Agronomy and Horticulture,

University of Nebraska-Lincoln,

310 Keim Hall,

Lincoln, NE 68583-0915, USA
}

higher nutrient removal rates indicate a potential for increased fertilization requirements over time. Switchgrass had consistently high biomass yields and relatively low nutrient removal rates (40 to $75 \mathrm{~kg} \mathrm{Nha}^{-1}, 5$ to $12 \mathrm{~kg} \mathrm{P}$ $\mathrm{ha}^{-1}$, and 44 to $110 \mathrm{~kg} \mathrm{Kha}^{-1}$ ) across years, demonstrating its merits as a low-input bioenergy crop.

Keywords Biomass yield · Biomass quality · Nitrogen fertilizer - Nutrient removal $\cdot$ Warm-season grasses

\section{Introduction}

Research sponsored by the US Department of Energy in the 1990s identified switchgrass (Panicum virgatum L.) as a model feedstock for energy production [1]. Switchgrass, a perennial grass native to North America, contained desirable agronomic and feedstock characteristics including high biomass yield potential, prolific seed production, adaptation to marginal environments, and high $\mathrm{N}$-use efficiency $[1,2]$. Studies have demonstrated origin, and ecotype of switchgrass cultivars affects its biomass yield potential $[3,4]$. In general, cultivars selected from plant materials originating from northern latitudes flower earlier, produce less biomass, and have a longer winter dormant period than cultivars derived from southern latitudes when grown in the same environment [3, 4]. Lowland ecotypes of switchgrass tend to have bunch-type growth forms, thicker stems, shorter rhizomes, and more biomass production than upland ecotypes [3, 4]. Maximum yields of switchgrass in single harvest per year, biomass for energy production systems have been obtained with $\mathrm{N}$ fertilizer rates typically ranging from 120 to $168 \mathrm{~kg} \mathrm{ha}^{-1}$, depending on cultivar, age of stand, and harvest time [5-7]. Several studies support harvesting of switchgrass after frost to maximize transloca- 
tion of nutrients to stem bases, rhizomes, and roots before harvest $[5,6,8]$.

Despite potential of switchgrass as a bioenergy crop, other perennial grasses, including giant miscanthus (Miscanthus $x$ giganteus) and giant reed (Arundo donax), show promise for biomass energy production [2]. Miscanthus, a C-4 species native to Southeast Asia, has produced dry matter yields ranging from 10 to $25 \mathrm{Mg} \mathrm{ha}^{-1}$ in central and northern Europe and above $30 \mathrm{Mg} \mathrm{ha}^{-1}$ under irrigated conditions in southern Europe [2]. In the USA, dry matter yields of miscanthus and switchgrass in side-by-side trials averaged 30 and $10 \mathrm{Mg} \mathrm{ha}^{-1}$ [9]. Giant reed, a C-3 species native to Europe, produced $23 \mathrm{Mg} \mathrm{ha}^{-1}$ across a 6-year study in Italy [10]. In another study in Italy, giant reed produced $38 \mathrm{Mg} \mathrm{ha}^{-1}$ by the third year after establishment compared to $27 \mathrm{Mg} \mathrm{ha}^{-1}$ produced by miscanthus [11]. Under nonfertilized conditions in Georgia, USA, dry matter yields of giant reed and switchgrass were similar, averaging 6.4 and 8.6 $\mathrm{Mg} \mathrm{ha}^{-1}[12]$.

Biomass for energy production also may come from locally adapted, perennial forage grasses. Dry biomass yields of switchgrass, bermudagrass (Cynodon dactylon), flaccidgrass (Pennisetum flaccidum), and weeping lovegrass increased with applications up to $134 \mathrm{~kg} \mathrm{Nha}^{-1}$, averaging $12.3,10.5,9.7$, and $9.2 \mathrm{Mg} \mathrm{ha}^{-1}$, respectively, in a single harvest per year system in Oklahoma, USA [13, 14]. Perennial grasses, such as kleingrass, weeping lovegrass, and Johnsongrass, have demonstrated high forage yield potential on marginal soils in this region [15]. A limitation to understanding the value of such grasses for biomass energy production systems is that their high biomass yields are often achieved through multiple defoliations per year. Fertilization requirements and biomass yield potential of these grasses under a single harvest system for biomass energy production has not been documented.

Sustainability of biomass energy production systems also depends on how fertilization rates affect concentration and removal of nutrients in harvested biomass [16-18]. Mineral concentrations affect biomass quality [19-21] and greater rates of removal in biomass harvests drive up fertilizer input costs $[13,14]$. Biomass quality depends on whether conversion systems use biochemical, thermochemical, or direct combustion processes [19, 20]. Perennial grasses remobilize nutrients from above to belowground structures across the growing season, which, depending on harvest period, has an effect on the levels of N, P, and $\mathrm{K}$ in harvested material $[19,22]$. Harvesting after plant senescence reduces mineral concentrations in biomass, desirable characteristics for direct combustion and thermochemical conversion systems $[19,20,22]$. Harvesting during early winter after a killing frost was recommended to minimize mineral concentrations and optimize biomass yields in perennial grass stands $[8,18,22]$.
Although a number of studies $[5,18]$ have evaluated biomass yields and fertilizer responses of switchgrass managed for biomass energy production, research on biomass yields, nutrient concentrations, and nutrient removal rates of other perennial grasses remains limited. Thus, the overall objective of this research was to begin to address this knowledge gap for the southern Great Plains region of USA. Specific aims within this study were to: (1) quantify effects of $\mathrm{N}$ fertilizer rate on biomass yields of locally adapted forage and promising biomass energy grasses including switchgrass, giant miscanthus, giant reed, weeping lovegrass, kleingrass, and Johnsongrass harvested once per year under a single, after-frost system; (2) document changes in nutrient concentrations among these grasses across the growing season; and (3) determine nutrient removal rates from these grasses in the single, after-frost harvest system.

\section{Materials and Methods}

\section{Experimental Design and Grass Establishment}

The research was conducted at The Samuel Roberts Noble Foundation Red River Research and Demonstration Farm near Burneyville, OK $\left(33^{\circ} 53^{\prime} \mathrm{N}, 97^{\circ} 16^{\prime} \mathrm{W}\right)$ from 2007 to 2010. Beginning in winter 2007, more than 600 individuals of the perennial grasses were established in a greenhouse with Metro-mix 350 rooting media (BWI Companies Inc., TX, USA). The media contained $45-55 \%$ horticultural grade vermiculite, bark, Canadian sphagnum peat moss, coarse perlite, bark ash, starter nutrient charge, gypsum and slow release nitrogen, and dolomitic limestone. Grass species included "EG1101" switchgrass (a selection derived from the cultivar Alamo), giant miscanthus, common giant reed, "Ermelo" weeping lovegrass, "Selection 75" kleingrass, and common Johnsongrass. Individuals of giant reed were propagated in 10.16-cm diameter pots from rhizomes, tillers, and stem cuttings collected from a local population near Ardmore $\left(34^{\circ} 10^{\prime} \mathrm{N}, 97^{\circ} 8^{\prime} \mathrm{W}\right)$. Individuals of giant miscanthus were propagated in 10.16-cm diameter pots from rhizomes obtained from John Caveny (Monticello, IL, USA). All other species were started from seed in flats with $6.45 \mathrm{~cm}^{2}$ cells. As these species outgrew their cells, they were transferred to $10.16-\mathrm{cm}$ pots. Growth was kept in check throughout spring 2008 with constant trimming at a $30.5-\mathrm{cm}$ height.

Following propagation in the greenhouse, the grasses were transplanted on 12 May 2008 into a tilled and disked Minco fine sandy loam soil (coarse-silty, mixed, superactive, thermic Udic Haplustolls). Six hundred individuals of each species were transplanted across $120,9.3-\mathrm{m}^{2}$ plots. The plots were arranged in a randomized complete block design to accompany the six grass species, four nitrogen fertilizer rates $\left(0,56,112\right.$, and $\left.168 \mathrm{~kg} \mathrm{Nha}^{-1}\right)$ and six 
replications. Twenty-five individuals of each species were transplanted in the monoculture plots at a $76.2-\mathrm{cm}$ spacing within and between rows. During transplanting, plants were placed in shallow holes, and soil was firmed around the roots to improve root-soil contact. Plants were watered before transport to the field and irrigated the morning after transplanting with $25.4 \mathrm{~mm}$ of water to ensure stand establishment.

\section{Stand Maintenance}

The seedbed was weed-free at the time of transplanting, but crabgrass (Digitaria sanguinalis (L.) Scop) became problematic during the first few weeks thereafter. Mechanical weed control measures done in early July of 2008 included a combination of mowing and tilling between plants. Due to the absence of labeled herbicides and a desire to avoid losing stands, chemical weed control was not used during this study. Ants were controlled using a granulated pesticide, Amdro (active ingredient hydramethylnon, Ambrand Inc., Atlanta, GA, USA), on 29 August 2008. Two months after transplanting, percentage survival of individual plants averaged $95 \%$ for giant reed, $98 \%$ for switchgrass, $100 \%$ for kleingrass, $91 \%$ for Johnsongrass, and $97 \%$ for weeping lovegrass, and $55 \%$ for giant miscanthus. Dead plants were replaced during this time with new transplants.

Soil samples were collected from $0-$ to $15-\mathrm{cm}$ depths in February 2009 and analyzed for $\mathrm{pH}$ at a 1:1 soil to water ratio [23], organic matter by high-temperature combustion [24], $\mathrm{P}$ by the Mehlich-3 procedure [25], and $\mathrm{K}$ via ammonium acetate extraction [26]. Soil had a $\mathrm{pH}$ of 5.3, $1.0 \%$ organic matter, $4 \mathrm{mg} \mathrm{Nkg}{ }^{-1}, 54 \mathrm{mg} \mathrm{Pkg}^{-1}$ and $60 \mathrm{mg} \mathrm{Kkg}{ }^{-1}$. In mid-March of each year, potassium chloride (0-0-60) at $134 \mathrm{~kg} \mathrm{~K}_{2} \mathrm{O} \mathrm{ha}^{-1}$ was applied to all plots. To minimize competition from weeds, $\mathrm{N}$ fertilizer rate treatments were not applied during establishment year of 2008. Urea $(0-0-46)$ was applied at $0,56,112$, or $168 \mathrm{~kg} \mathrm{Nha}^{-1}$ to the assigned experimental units on $27 \mathrm{Mar}$ 2009 and 20 Apr 2010.

\section{Biomass Harvesting and Analysis}

Whole-plot biomass yields were determined for each species during winter on 22 December 2009 and 26 January 2011. First fall frosts $\left(<-2.5^{\circ} \mathrm{C}\right)$ occurred on 26 November 2009 and 25 November 2010. Whole-plot biomass was harvested at a $10-\mathrm{cm}$ height from a $0.91 \times$ $3.05-\mathrm{m}$ strip through the center of each plot with a Carter flail harvester (Carter Mfg Co., Inc., Brookston, IN, USA). Subsamples of the harvested biomass were then removed for determination of dry matter yield, analysis of nutrient concentrations $(\mathrm{N}, \mathrm{P}, \mathrm{K}, \mathrm{Ca}$, and
$\mathrm{Mg}$ ), and calculation of nutrient removal rates. Subsamples of biomass also were collected by clipping one individual plant of each species outside of the center strip at a $10-\mathrm{cm}$ height in May, June, July, October, and December to determine how concentrations of N, P, K, $\mathrm{Ca}$, and $\mathrm{Mg}$ varied across the growing season. In the October and December biomass collections, whole-plant subsamples of switchgrass and giant reed were further separated into stem, leaf, and inflorescence fractions to determine how nutrient concentrations varied among these fractions. Following all harvests, biomass samples were dried at $60^{\circ} \mathrm{C}$ in a forced-air oven for 3-4 days and then ground to pass a $<1 \mathrm{~mm}$ screen using a Wiley Mill (Thomas Scientific, Swedesboro, NJ, USA).

Biomass samples were analyzed for $\mathrm{N}, \mathrm{P}, \mathrm{K}, \mathrm{Ca}$, and $\mathrm{Mg}$ using the Foss 6500 near infra-red reflectance spectroscopy (NIRS) instrument. The samples were scanned using Foss ISI Scan software and prediction equations developed by the NIRS Forage and Feed Testing Consortium (Hillsboro, WI, USA). The N concentration mean, standard error of validation, and $r^{2}$ for the equation were 19.9, 1.3, and $0.98 \mathrm{gkg}^{-1}$, respectively. The $\mathrm{P}$ mean, standard error of validation, and $r^{2}$ for the equation were $1.9,0.4$, and $0.73 \mathrm{~g} \mathrm{~kg}^{-1}$, respectively. The $\mathrm{K}$ mean, standard error of validation, and $r^{2}$ for the equation were 16, 2.8, and $0.85 \mathrm{~g} \mathrm{~kg}^{-1}$, respectively. The $\mathrm{Ca}$ mean, standard error of validation, and $r^{2}$ for the equation were $4.9,0.9$, and $0.84 \mathrm{~g} \mathrm{~kg}^{-1}$, respectively. The $\mathrm{Mg}$ mean, standard error of validation, and $r^{2}$ for the equation were 2.6, 0.5 , and $0.91 \mathrm{~g} \mathrm{~kg}^{-1}$, respectively. These equations were then used to predict $\mathrm{N}$, $\mathrm{P}, \mathrm{K}, \mathrm{Ca}$, and $\mathrm{Mg}$ for all samples.

An analysis of repeated measures data was conducted using the PROC MIXED procedure in SAS [27] to determine main effects and interactions of $\mathrm{N}$ rate, grass species, and year since data were collected on the same experimental unit across the 2 years of the experiment. Grass species, $\mathrm{N}$ rate, and year were considered fixed effects, and replications were considered random effects. Significance was determined at the $P<0.05$ level. The PDIFF feature of the LSMEANS procedure was used to compare means. Single degree of freedom contrasts were used to evaluate linear, quadratic, and cubic effects of nitrogen fertilizer on biomass. A repeated measures analysis using the mixed-models procedure also was conducted to determine main effects and interactions of $\mathrm{N}$ rate, species, and year on nutrient concentrations at the different biomass sampling periods (May, June, July, October, and December) and on nutrient concentration in the leaves and stems of switchgrass and giant reed (October and December). The statistical models applied the autoregressive (AR1) spatial power covariance structure to account for temporal data collection across years. 


\section{Results}

\section{Growing Conditions}

During the establishment year of 2008, precipitation was lower (30-88\%) than the long-term 30-year average for all months from April through December, except for August (Table 1). While it was higher in 2009, precipitation in 2010 was comparable to long-term 30-year average (Table 1). Due to lower than average monthly precipitation in June (16\% and 64\%) and August (41\% and 49\%) during the production years, supplemental irrigation $\left(25.4 \mathrm{~mm}^{\text {day }}{ }^{-1}\right)$ was carried out on appropriate days during these months. Total annual amount (precipitation+irrigation) was $1,404 \mathrm{~mm}$ in 2009 and 1,040 $\mathrm{mm}$ in 2010. Although mean temperature in June during production years was $1.6^{\circ} \mathrm{C}$ higher than long-term 30-year average, mean annual temperature was $0.6^{\circ} \mathrm{C}$ lower.

\section{Biomass Yield}

\section{Species}

Year by species interactions for biomass yield were significant $(P<0.01)$; therefore, means were reported by species. Biomass yield of giant reed increased by $18 \%$ from 21.4 $\mathrm{Mg} \mathrm{ha}^{-1}$ in 2009 to $25.3 \mathrm{Mg} \mathrm{ha}^{-1}$ in 2010 , whereas, biomass yield of all other species declined from 2009 to 2010 (Table 2). Biomass yield of switchgrass and Johnsongrass did not differ in 2009 and 2010 (17.8 and $6.0 \mathrm{Mg} \mathrm{ha}^{-1}$, respectively). Whereas, biomass yield of kleingrass and weeping lovegrass declined from 16.0 and $29.0 \mathrm{Mg} \mathrm{ha}^{-1}$ in
2009 to 9.8 and $13.0 \mathrm{Mg} \mathrm{ha}^{-1}$ in 2010 (39\% and 55\%, respectively). Due to poor establishment after transplanting in 2008 , giant miscanthus produced only 3.4 and $6.0 \mathrm{Mg} \mathrm{ha}^{-1}$ in 2009 and 2010, respectively. Giant miscanthus may need more precipitation or it may not be well adapted to sandy soils compared to these other species.

\section{$N$ Rate}

Year by $\mathrm{N}$ rate interactions were not significant $(P=0.78)$, but species by $\mathrm{N}$ rate interactions were significant $(P=0.02)$, therefore, means were pooled across years and reported by species. Biomass yield of giant reed increased in a linear manner from $19.4 \mathrm{Mg} \mathrm{ha}^{-1}$ at $0 \mathrm{~kg} \mathrm{Nha}^{-1}$ to $33.2 \mathrm{Mg} \mathrm{ha}^{-1}$ at $168 \mathrm{~kg} \mathrm{Nha}^{-1}$ (Table 2). Biomass yield of switchgrass increased in a linear manner from $14.7 \mathrm{Mg} \mathrm{ha}^{-1}$ at $0 \mathrm{~kg} \mathrm{Nha}{ }^{-1}$ to $19.7 \mathrm{Mg} \mathrm{ha}^{-1}$ at $112 \mathrm{~kg} \mathrm{Nha}^{-1}$. Biomass yield of Johnsongrass increased quadratically with $\mathrm{N}$ fertilizer rate up to $112 \mathrm{~kg} \mathrm{Nha}^{-1}$. Weeping lovegrass, giant miscanthus, and kleingrass showed no response to $\mathrm{N}$ fertilizer rate.

\section{Nutrient Concentrations}

Year by species and year by sampling period interactions were not significant; however, sampling period by species interactions were significant for $\mathrm{N}, \mathrm{P}, \mathrm{K}, \mathrm{Ca}$, and $\mathrm{Mg}$ concentrations. Therefore, means were reported by species and by sampling period averaged across years (Table 3 ). Nutrient concentrations declined across the growing season in all species. In May, giant reed had $33.8 \mathrm{gN} \mathrm{kg}^{-1}$ compared to $23.7,20.3,18.9$, and $18.6 \mathrm{gkg}^{-1}$ found in
Table 1 Precipitation and temperature across 2008, 2009, 2010 , and 30 -year average for Burneyville, Oklahoma, USA

\begin{tabular}{|c|c|c|c|c|c|c|c|c|}
\hline \multirow[t]{2}{*}{ Month } & \multicolumn{4}{|c|}{ Precipitation } & \multicolumn{4}{|c|}{ Temperature } \\
\hline & $\begin{array}{l}\text { Average } \\
-(\mathrm{mm})-\end{array}$ & 2008 & 2009 & 2010 & $\begin{array}{l}\text { Average } \\
-\left({ }^{\circ} \mathrm{C}\right)-\end{array}$ & 2008 & 2009 & 2010 \\
\hline January & 43 & 3 & 9 & 46 & 5.5 & 4.8 & 5.1 & 4.0 \\
\hline February & 53 & 32 & 40 & 71 & 8.1 & 8.2 & 11.0 & 3.6 \\
\hline March & 86 & 142 & 48 & 71 & 12.4 & 12.9 & 13.6 & 11.0 \\
\hline April & 84 & 59 & 390 & 74 & 17.5 & 16.8 & 16.8 & 17.3 \\
\hline May & 130 & 90 & 125 & 107 & 21.7 & 21.7 & 20.2 & 21.7 \\
\hline June & 107 & 61 & 63 & 55 & 26.0 & 27.3 & 27.2 & 28.0 \\
\hline July & 56 & 15 & 85 & 129 & 28.6 & 29.0 & 27.9 & 27.9 \\
\hline August & 69 & 90 & 58 & 25 & 28.2 & 26.8 & 27.2 & 29.5 \\
\hline September & 102 & 36 & 181 & 173 & 24.1 & 21.8 & 21.9 & 24.2 \\
\hline October & 112 & 32 & 204 & 74 & 18.4 & 17.4 & 14.6 & 17.0 \\
\hline November & 69 & 13 & 6 & 35 & 11.9 & 11.6 & 12.9 & 12.2 \\
\hline December & 61 & 7 & 93 & 51 & 6.8 & 6.0 & 2.8 & 6.5 \\
\hline Total $(\mathrm{mm})$ or mean $\left({ }^{\circ} \mathrm{C}\right)$ & 972 & 580 & 1,302 & 912 & 17.4 & 17.0 & 16.8 & 16.9 \\
\hline
\end{tabular}


Table 2 Total annual biomass yield in response to $\mathrm{N}$ fertilizer rate of perennial grass species at Burneyville, Oklahoma, USA

Upper and lower case letters are for column and row comparison, respectively. For each variable (Year and $\mathrm{N}$ rate), values with same letter on a row or column are not significantly different at $P=0.05$

\begin{tabular}{lcccccc}
\hline Variable & $\begin{array}{c}\text { Giant reed } \\
-\mathrm{Mg} \mathrm{DM} \mathrm{ha} \mathrm{ha}^{-1}-\end{array}$ & Switchgrass & Kleingrass & Johnsongrass & Weeping lovegrass & Miscanthus \\
\hline Year & & & & & \\
2009 & $21.4 \mathrm{bY}$ & $19.5 \mathrm{bcY}$ & $16.0 \mathrm{cY}$ & $6.9 \mathrm{dY}$ & $29.0 \mathrm{aY}$ & $3.4 \mathrm{eY}$ \\
2010 & $25.3 \mathrm{aY}$ & $16.0 \mathrm{bY}$ & $9.8 \mathrm{cdZ}$ & $5.0 \mathrm{dY}$ & $13.0 \mathrm{bcZ}$ & $6.0 \mathrm{dY}$ \\
$\mathrm{N}$ rate & & & & & & \\
0 & $19.4 \mathrm{abZ}$ & $14.7 \mathrm{abY}$ & $13.7 \mathrm{bcY}$ & $4.1 \mathrm{cY}$ & $21.0 \mathrm{aY}$ & $4.2 \mathrm{cY}$ \\
56 & $23.4 \mathrm{aZ}$ & $17.2 \mathrm{abY}$ & $9.6 \mathrm{bcY}$ & $6.4 \mathrm{cY}$ & $22.5 \mathrm{aY}$ & $4.8 \mathrm{bY}$ \\
112 & $17.2 \mathrm{abZ}$ & $19.7 \mathrm{aY}$ & $12.5 \mathrm{bcY}$ & $7.4 \mathrm{cY}$ & $22.3 \mathrm{aY}$ & $4.7 \mathrm{dY}$ \\
168 & $33.2 \mathrm{aY}$ & $19.5 \mathrm{bY}$ & $15.8 \mathrm{bY}$ & $6.1 \mathrm{cY}$ & $18.2 \mathrm{bY}$ & $5.2 \mathrm{cY}$ \\
$-\mathrm{P}-$ value- & & & & & & 0.49 \\
Linear & 0.08 & 0.09 & 0.25 & 0.07 & 0.43 & 0.46 \\
Quadratic & 0.16 & 0.55 & 0.09 & 0.04 & \\
\hline
\end{tabular}

Table 3 Seasonal changes in whole-plant $\mathrm{N}, \mathrm{P}, \mathrm{K}, \mathrm{Ca}$, and $\mathrm{Mg}$ concentration of perennial grasses pooled across 2009 and 2010 seasons at Burneyville, Oklahoma, USA
Values for a given element on a given month followed by same letter are not significantly different at $P=0.05$

\begin{tabular}{|c|c|c|c|c|c|c|}
\hline Sampling period & Giant reed & Switchgrass & Kleingrass & Johnsongrass & $\begin{array}{l}\text { Weeping } \\
\text { lovegrass }\end{array}$ & Miscanthus \\
\hline \multicolumn{7}{|l|}{$-\mathrm{g} \mathrm{Nkg}^{-1}-$} \\
\hline May & $33.8 \mathrm{a}$ & $18.9 \mathrm{~d}$ & $23.7 b$ & $24.2 \mathrm{~b}$ & $18.6 \mathrm{~d}$ & $20.3 \mathrm{c}$ \\
\hline June & $24.7 \mathrm{a}$ & $13.1 \mathrm{c}$ & $13.9 \mathrm{bc}$ & $15.0 \mathrm{~b}$ & $13.9 \mathrm{bc}$ & $14.9 \mathrm{~b}$ \\
\hline July & $16.6 \mathrm{a}$ & $9.6 \mathrm{c}$ & $10.4 \mathrm{bc}$ & $11.1 \mathrm{~b}$ & $11.3 \mathrm{~b}$ & $10.3 \mathrm{bc}$ \\
\hline October & $15.1 \mathrm{a}$ & $6.9 \mathrm{~d}$ & $12.2 \mathrm{~b}$ & $12.2 \mathrm{~b}$ & $12.8 \mathrm{~b}$ & $8.0 \mathrm{c}$ \\
\hline $\begin{array}{l}\text { December } \\
-\mathrm{g} \mathrm{Pkg}^{-1}-\end{array}$ & $9.3 b$ & $3.7 \mathrm{~d}$ & $7.3 \mathrm{c}$ & $11.1 \mathrm{a}$ & $10.5 \mathrm{a}$ & $7.9 \mathrm{c}$ \\
\hline May & $2.83 \mathrm{a}$ & $2.38 \mathrm{c}$ & $2.47 \mathrm{~b}$ & $2.48 \mathrm{~d}$ & $2.03 \mathrm{~d}$ & $2.33 \mathrm{c}$ \\
\hline June & $2.56 \mathrm{a}$ & $2.08 b$ & $2.02 \mathrm{bc}$ & $1.96 \mathrm{c}$ & $1.7 \mathrm{~d}$ & $1.99 \mathrm{c}$ \\
\hline July & $2.21 \mathrm{a}$ & $1.91 \mathrm{~b}$ & $1.75 \mathrm{c}$ & $1.77 \mathrm{c}$ & $1.52 \mathrm{~d}$ & $1.77 \mathrm{c}$ \\
\hline October & $1.82 \mathrm{a}$ & $1.31 \mathrm{~d}$ & $1.51 \mathrm{~b}$ & $1.34 \mathrm{~cd}$ & $1.38 \mathrm{bc}$ & $1.77 \mathrm{a}$ \\
\hline $\begin{array}{l}\text { December } \\
-\mathrm{g} \mathrm{Kkg}^{-1}-\end{array}$ & $1.13 \mathrm{a}$ & $0.92 \mathrm{c}$ & $0.86 \mathrm{~cd}$ & $0.84 \mathrm{~d}$ & $1.04 \mathrm{~b}$ & $0.72 \mathrm{e}$ \\
\hline May & $19.9 \mathrm{~cd}$ & $20.8 \mathrm{bc}$ & $21.6 \mathrm{ab}$ & $19.6 \mathrm{~d}$ & $15.9 \mathrm{e}$ & $22.7 \mathrm{a}$ \\
\hline June & $17.4 \mathrm{ab}$ & $18.3 \mathrm{a}$ & $17.7 \mathrm{ab}$ & $16.7 \mathrm{~b}$ & $14.6 \mathrm{c}$ & $18.6 \mathrm{a}$ \\
\hline July & $15.6 \mathrm{a}$ & $15.3 \mathrm{ab}$ & $14.5 \mathrm{~b}$ & $15.4 \mathrm{ab}$ & $12.3 \mathrm{c}$ & $17.6 \mathrm{a}$ \\
\hline October & $11.7 \mathrm{a}$ & $7.3 \mathrm{e}$ & $10.2 \mathrm{bc}$ & $8.6 \mathrm{~d}$ & $9.5 \mathrm{~cd}$ & $10.9 \mathrm{ab}$ \\
\hline $\begin{array}{l}\text { December } \\
-\mathrm{g} \mathrm{Ca} \mathrm{kg}^{-1}-\end{array}$ & $5.1 b$ & $7.2 \mathrm{a}$ & $5.3 b$ & $3.8 \mathrm{c}$ & $4.6 \mathrm{~b}$ & $7.2 \mathrm{a}$ \\
\hline May & $6.5 \mathrm{a}$ & $3.6 \mathrm{c}$ & $4.4 \mathrm{~b}$ & $6.4 \mathrm{a}$ & $3.1 \mathrm{~d}$ & $4.7 b$ \\
\hline June & $5.8 \mathrm{a}$ & $3.0 \mathrm{~d}$ & $4.2 \mathrm{~b}$ & $5.6 \mathrm{a}$ & $3.7 \mathrm{c}$ & $4.2 \mathrm{~b}$ \\
\hline July & $5.1 \mathrm{a}$ & $2.9 \mathrm{~d}$ & $4.0 \mathrm{~b}$ & $5.3 \mathrm{a}$ & $3.0 \mathrm{~d}$ & $3.6 \mathrm{c}$ \\
\hline October & $4.8 \mathrm{a}$ & $2.9 b c$ & $3.1 b$ & $5.1 \mathrm{a}$ & $2.5 \mathrm{c}$ & $4.8 \mathrm{a}$ \\
\hline $\begin{array}{l}\text { December } \\
-\mathrm{g} \mathrm{Mg} \mathrm{kg}^{-1}-\end{array}$ & $4.6 \mathrm{a}$ & $2.3 b$ & $2.5 \mathrm{c}$ & $4.8 \mathrm{a}$ & $2.6 \mathrm{~b}$ & $4.9 \mathrm{a}$ \\
\hline May & $6.1 \mathrm{a}$ & $4.4 \mathrm{c}$ & $4.1 \mathrm{~cd}$ & $5.8 \mathrm{~b}$ & $2.8 \mathrm{e}$ & $3.9 \mathrm{~d}$ \\
\hline June & $5.8 \mathrm{a}$ & $3.6 \mathrm{c}$ & $3.6 \mathrm{c}$ & $5.1 \mathrm{~b}$ & $2.2 \mathrm{e}$ & $3.7 \mathrm{~d}$ \\
\hline July & $4.8 \mathrm{a}$ & $3.5 \mathrm{c}$ & $3.3 \mathrm{c}$ & $4.4 \mathrm{~b}$ & $1.9 \mathrm{~d}$ & $3.1 \mathrm{c}$ \\
\hline October & $4.1 \mathrm{a}$ & $2.8 \mathrm{~b}$ & $2.5 \mathrm{c}$ & $4.2 \mathrm{a}$ & $1.8 \mathrm{~d}$ & $2.5 \mathrm{c}$ \\
\hline December & $3.4 \mathrm{a}$ & $2.4 \mathrm{~d}$ & $2.4 \mathrm{~d}$ & $3.0 \mathrm{~b}$ & $1.4 \mathrm{e}$ & $2.7 \mathrm{c}$ \\
\hline
\end{tabular}


kleingrass, giant miscanthus, switchgrass, and weeping lovegrass, respectively. By October, $\mathrm{N}$ concentration had dropped by $50 \%$ in all grass species with switchgrass showing the lowest concentration at $6.9 \mathrm{~g} \mathrm{~kg}^{-1}$. Between October and December, $\mathrm{N}$ content dropped by more than $50 \%$ in switchgrass and kleingrass but only by $22 \%$ to $38 \%$ in weeping lovegrass, giant miscanthus, and giant reed. Across years, tissue $\mathrm{P}$ concentration ranged between 2.03 and $2.83 \mathrm{~g} \mathrm{~kg}^{-1}$ in May. In all grass species, $\mathrm{P}$ concentration dropped $25 \%$ to $48 \%$ from May to October and by $\geq 50 \%$ from October to December, diminishing to approximately $1.0 \mathrm{~g} \mathrm{~kg}^{-1}$ by harvest time. Across years, $\mathrm{K}$ concentration ranged from 15.9 to $22.7 \mathrm{~g} \mathrm{~kg}^{-1}$ in May, with weeping lovegrass having the lowest concentration. Biomass $\mathrm{K}$ concentration dropped by up to $50 \%$ by October in nearly all species to $<12 \mathrm{~g} \mathrm{~kg}^{-1}$. The drop in $\mathrm{K}$ contents between October and December averaged $49 \%$ in all species except switchgrass which showed slight changes. In all species, $\mathrm{K}$ concentration by harvest time in winter ranged from 2.3 to $4.3 \mathrm{~g} \mathrm{~kg}^{-1}$. Similar to other nutrients, $\mathrm{Ca}$ and $\mathrm{Mg}$ concentrations declined from May through December. However, changes in concentration of these two elements were relatively small, $<20 \%$ between October and December. Giant reed and Johnsongrass maintained the highest concentration of $\mathrm{Ca}$ and $\mathrm{Mg}$ throughout the season while weeping lovegrass maintained the lowest concentration.

A notable pattern observed with giant reed was a significant amount of leaf loss between biomass sampling in October and December (Table 4). The number of leaves per stem of giant reed declined from 36 during the fall to 6 by winter. The percentage of biomass in leaves was $20 \%$ and $32 \%$ in October and $15 \%$ and $<3 \%$ in December for switchgrass and giant reed, respectively (Table 5). Average leaf weight dropped drastically for giant reed from $1.39 \mathrm{~g}$ in October to $0.75 \mathrm{~g}$ in winter (Table 4). In switchgrass, a smaller reduction in leaf weight between October and December was observed. Except for stem moisture content in October, moisture content within leaves and stems of giant reed was higher than that within leaves and stems of switchgrass. In general, nutrient concentrations were higher in leaves and stems of giant reed $(P=0.05)$ than in leaves and stems of switchgrass during both the October and December sampling times. Leaves also had comparatively higher mineral element concentrations than stems for the two grasses (Table 4). Based on the leaf mass to stem mass ratio, harvesting giant reed in the fall compared to winter would result in a higher biomass yield but the biomass would have much greater nutrient concentrations.
Table 4 Average leaf and stem weights, moisture content, and nutrient concentration of switchgrass and giant reed in October and December

Values for with different letters on a row for a given element are significantly different at $P=0.05$

\begin{tabular}{|c|c|c|c|c|}
\hline \multirow[t]{2}{*}{ Fraction } & \multicolumn{2}{|l|}{ October } & \multicolumn{2}{|l|}{ December } \\
\hline & Giant reed & Switchgrass & Giant reed & Switchgrass \\
\hline Leaves stem ${ }^{-1}$ & $36 \mathrm{a}$ & $7 \mathrm{~b}$ & $6 a$ & $6 a$ \\
\hline Leaf mass stem mass ${ }^{-1}$ & $0.32 \mathrm{a}$ & $0.20 \mathrm{~b}$ & $0.02 b$ & $0.15 \mathrm{a}$ \\
\hline Leaf moisture (\%) & $57.6 \mathrm{a}$ & $43.8 b$ & $12.5 \mathrm{a}$ & $4.9 \mathrm{~b}$ \\
\hline $\begin{array}{l}\text { Stem moisture }(\%) \\
- \text { g plant }^{-1}-\end{array}$ & $51.1 \mathrm{a}$ & $50.6 \mathrm{a}$ & $43.3 \mathrm{a}$ & $20.6 b$ \\
\hline Leaf & $50.0 \mathrm{a}$ & $1.86 \mathrm{c}$ & $4.5 \mathrm{a}$ & $1.1 \mathrm{~b}$ \\
\hline $\begin{array}{l}\text { Stem } \\
-\mathrm{g} \mathrm{Nkg}^{-1}-\end{array}$ & $154 \mathrm{a}$ & $9.2 \mathrm{~b}$ & $174 a$ & $7.4 \mathrm{~b}$ \\
\hline Leaf & $23.0 \mathrm{a}$ & $11.6 b$ & $15.6 \mathrm{a}$ & $7.6 \mathrm{~b}$ \\
\hline $\begin{array}{l}\text { Stem } \\
-\mathrm{g} \mathrm{Pkg}^{-1}-\end{array}$ & $10.3 \mathrm{a}$ & $5.5 \mathrm{~b}$ & $3.8 \mathrm{a}$ & $1.4 \mathrm{~b}$ \\
\hline Leaf & $2.46 \mathrm{a}$ & $1.27 \mathrm{~b}$ & $1.69 \mathrm{a}$ & $1.10 \mathrm{~b}$ \\
\hline $\begin{array}{l}\text { Stem } \\
-\mathrm{g} \mathrm{Kkg}^{-1}-\end{array}$ & $1.47 \mathrm{a}$ & $1.22 \mathrm{~b}$ & $1.25 \mathrm{a}$ & $1.11 \mathrm{~b}$ \\
\hline Leaf & $11.7 \mathrm{a}$ & $5.7 \mathrm{~b}$ & $6.3 \mathrm{a}$ & $2.3 b$ \\
\hline $\begin{array}{l}\text { Stem } \\
-\mathrm{g} \mathrm{Ca} \mathrm{kg}^{-1}-\end{array}$ & $10.0 \mathrm{a}$ & $7.1 \mathrm{~b}$ & $6.0 \mathrm{a}$ & $4.5 b$ \\
\hline Leaf & $7.9 \mathrm{a}$ & $4.5 b$ & $6.4 \mathrm{a}$ & $5.9 \mathrm{a}$ \\
\hline $\begin{array}{l}\text { Stem } \\
-\mathrm{g} \mathrm{Mg} \mathrm{kg}^{-1}-\end{array}$ & $3.1 \mathrm{a}$ & $2.7 \mathrm{a}$ & $1.0 \mathrm{a}$ & $1.2 \mathrm{a}$ \\
\hline Leaf & $6.8 \mathrm{a}$ & $4.3 b$ & $4.6 \mathrm{a}$ & $3.8 \mathrm{~b}$ \\
\hline Stem & $2.7 \mathrm{a}$ & $2.6 \mathrm{a}$ & $2.2 \mathrm{~b}$ & $2.5 \mathrm{a}$ \\
\hline
\end{tabular}


Table 5 Removal of N, P, K, $\mathrm{Ca}$, and $\mathrm{Mg}$ in biomass harvested after frost (December) at Burneyville, Oklahoma, USA

Values for a given element followed by same letter are not significantly different at $P=0.05$

\begin{tabular}{|c|c|c|c|c|c|c|}
\hline Year & Giant reed & Switchgrass & Kleingrass & Johnsongrass & Weeping lovegrass & Miscanthus \\
\hline \multicolumn{7}{|c|}{$-\mathrm{kg} \mathrm{Nkg}^{-1}-$} \\
\hline 2009 & $228 b$ & $75 \mathrm{def}$ & $104 d$ & $85 \mathrm{de}$ & $327 \mathrm{a}$ & $20 \mathrm{~g}$ \\
\hline 2010 & $162 \mathrm{c}$ & $40 \mathrm{e}$ & $74 \mathrm{efg}$ & $54 \mathrm{fg}$ & $118 \mathrm{~cd}$ & $31 \mathrm{~g}$ \\
\hline \multicolumn{7}{|c|}{$-\mathrm{kg} \mathrm{Pkg}^{-1}-$} \\
\hline 2009 & $25 \mathrm{ab}$ & $16 \mathrm{c}$ & $12 \mathrm{~cd}$ & $4 \mathrm{fg}$ & $29 a$ & $3 g$ \\
\hline 2010 & $23 b$ & $11 \mathrm{~cd}$ & $5 \mathrm{ef}$ & $2 \mathrm{fg}$ & 10de & $4 f g$ \\
\hline \multicolumn{7}{|c|}{$-\mathrm{kg} \mathrm{Kkg}^{-1}-$} \\
\hline 2009 & $121 \mathrm{bc}$ & $136 a b c$ & $110 \mathrm{c}$ & $38 \mathrm{de}$ & $162 \mathrm{a}$ & $24 \mathrm{e}$ \\
\hline 2010 & $149 \mathrm{ab}$ & $141 \mathrm{abc}$ & 44de & $23 \mathrm{e}$ & $61 d$ & $43 \mathrm{de}$ \\
\hline \multicolumn{7}{|c|}{$-\mathrm{kg} \mathrm{Ca} \mathrm{kg}^{-1}-$} \\
\hline 2009 & $136 a$ & $66 b$ & $61 b$ & $53 b$ & $120 \mathrm{a}$ & $20 \mathrm{c}$ \\
\hline 2010 & $68 \mathrm{~b}$ & $24 \mathrm{c}$ & $20 \mathrm{~cd}$ & $21 \mathrm{c}$ & $17 \mathrm{c}$ & $18 \mathrm{c}$ \\
\hline \multicolumn{7}{|c|}{$-\mathrm{kg} \mathrm{Mg} \mathrm{kg}^{-1}-$} \\
\hline 2009 & $111 \mathrm{a}$ & $63 b$ & $51 \mathrm{~b}$ & $32 \mathrm{c}$ & $58 \mathrm{~b}$ & $14 d$ \\
\hline 2010 & $53 b$ & $32 \mathrm{c}$ & $20 \mathrm{~cd}$ & $15 \mathrm{~d}$ & $13 d$ & $9 d$ \\
\hline
\end{tabular}

\section{Nutrient Removal}

Year by species interactions for nutrient removal were significant $(P<0.01$, Table 5$)$ and similar to biomass yield interactions. Therefore, means were reported by year and species. In 2009, weeping lovegrass removed the highest amounts of $\mathrm{N}$ at $327 \mathrm{~kg} \mathrm{Nha}^{-1}$ followed by giant reed at $228 \mathrm{~kg} \mathrm{Nha}^{-1}$ (Table 5). Giant miscanthus removed the lowest amount, $20 \mathrm{~kg} \mathrm{Nha}^{-1}$ (Table 5). Other species removed $\mathrm{N}$ at rates ranging from 75 to $104 \mathrm{~kg} \mathrm{Nha}^{-1}$ in 2009; whereas $\mathrm{N}$ removal in 2010 ranged from 31 to $162 \mathrm{~kg} \mathrm{Nha}^{-1}$. Phosphorus removal rates varied by year and species. In 2009, P removal rates were greatest for giant reed and weeping lovegrass (25 and $29 \mathrm{~kg} \mathrm{Pha}^{-1}$, respectively) followed by switchgrass and kleingrass (16 and $12 \mathrm{~kg} \mathrm{Pha}^{-1}$, respectively), while giant miscanthus and Johnsongrass had the least ( 3 and $4 \mathrm{~kg} \mathrm{Pha}^{-1}$, respectively). In 2010, P removal rates were greatest for giant reed (23 $\mathrm{kg} \mathrm{Pha}^{-1}$ ), followed by switchgrass and weeping lovegrass (11 and $10 \mathrm{~kg} \mathrm{Pha}^{-1}$, respectively) followed by kleingrass, giant miscanthus, and Johnsongrass $(5,4$, and $2 \mathrm{~kg} \mathrm{Pha}^{-1}$, respectively). Potassium removal rates also varied by year and species. Amount of K removed in 2009 and 2010 were similar for giant reed, switchgrass, and Johnsongrass and averaged removed 136, 134, and $30 \mathrm{~kg} \mathrm{ha}^{-1}$, respectively. Weeping lovegrass and kleingrass had $80 \%$ to $268 \%$ greater removal in 2009 (162 and $110 \mathrm{~kg} \mathrm{Kha}{ }^{-1}$ ) compared to 2010 (44 and $61 \mathrm{~kg} \mathrm{Kha}^{-1}$ ), respectively. Giant miscanthus removed $80 \%$ less in 2009 compared to 2010 (24 and $43 \mathrm{~kg} \mathrm{Kha}^{-1}$ in 2009 and 2010 , respectively).

Calcium removal followed similar trend in that 2009 removal rates were $11 \%$ to $606 \%$ greater than 2010 . In
2009, Ca removal rates were greatest for giant reed and weeping lovegrass (136 and $120 \mathrm{~kg} \mathrm{Ca} \mathrm{ha}^{-1}$, respectively) followed by switchgrass, kleingrass, and Johnsongrass (66, 61 , and $53 \mathrm{~kg} \mathrm{Ca} \mathrm{ha}^{-1}$ ), while giant miscanthus had the least $20 \mathrm{~kg} \mathrm{Ca} \mathrm{ha}^{-1}$. In 2010, Ca removal was greatest for giant reed $\left(68 \mathrm{~kg} \mathrm{Ca} \mathrm{ha}^{-1}\right)$, while the other species did not differ ranging from 17 to $24 \mathrm{~kg} \mathrm{Ca} \mathrm{ha}{ }^{-1}$. Magnesium removal also followed similar trend in that 2009 removal rates were $55 \%$ to $346 \%$ greater than 2010 . In $2009, \mathrm{Mg}$ removal rates were greatest for giant reed $\left(111 \mathrm{~kg} \mathrm{Mg} \mathrm{ha}^{-1}\right)$, followed by switchgrass, kleingrass, and weeping lovegrass (51 to $63 \mathrm{~kg} \mathrm{Mg} \mathrm{ha}^{-1}$ ). Johnsongrass and giant miscanthus removed the least amount ( 32 and $14 \mathrm{~kg} \mathrm{ha}^{-1}$, respectively). In $2010, \mathrm{Mg}$ removal was greatest for giant reed (53 $\mathrm{kg} \mathrm{Mg} \mathrm{ha}{ }^{-1}$ ) followed by switchgrass and kleingrass (20 to $32 \mathrm{~kg} \mathrm{Mg} \mathrm{ha}{ }^{-1}$ ), while Johnsongrass, weeping lovegrass, and giant miscanthus removed the least (9 to $15 \mathrm{~kg} \mathrm{Mg} \mathrm{ha}^{-1}$ ).

\section{Discussion}

Giant reed showed tremendous potential for biomass yield. Higher biomass yield than the other grasses in the first year after establishment may have been due in part to its relatively larger vegetatively propagated transplants. These large transplants led to faster growth and an almost $100 \%$ transplant success in the establishment year of 2008. In the year after establishment, rhizomes had spread in the plot increasing tiller density. Had giant reed retained its leaves after a killing frost, biomass yield at harvest in winter may have been 30\% higher. Leaf loss upon senescence appeared to be biased towards larger leaves as the average weight of 
a giant reed leaf in winter was $50 \%$ lower than that in the fall. High wind speeds, commonly experienced in the Great Plains, may lead to preferential loss of older and larger lower leaves compared to relatively young and smaller upper leaves. The tall height of giant reed, up to 3-4 $\mathrm{m}$ at physiological maturity, may have compounded leaf loss problems because of displacement and vibration from its vertical position during windy conditions [28]. Despite being a C-3 species growing on sandy soil in this southern environment, biomass yield of giant reed was higher than that of the other C-4 species grasses. Physiological and morphological traits that may support high biomass yields of giant reed including high net photosynthetic $\mathrm{CO}_{2}$ uptake rates of $37 \mu \mathrm{mol} \mathrm{m} \mathrm{s}^{-1}$, lack of light saturation, and little photoinhibition have been reported [29]. Giant reed grows in dense clumps, produces stems from dense, knotty rhizomes, and tolerates a wide range of soil conditions and types, surviving under wet and dry conditions [2].

Switchgrass biomass yields were similar between years and averaged $17.8 \mathrm{Mg} \mathrm{ha}^{-1}$. These biomass yields were comparable to that reported before for the southeastern and south-central USA [16, 18, 30, 31], but higher than those reported for Midwestern states [7, 22]. Concentration of $\mathrm{N}$ in biomass sampled in July or December also were comparable to those reported earlier $[16,18,30]$. Concentration of $\mathrm{P}$ was comparable to those reported for Alamo receiving $38 \mathrm{~kg} \mathrm{Nha}^{-1}$ in Tennessee [16] and $112 \mathrm{~kg} \mathrm{Nha}^{-1}$ in south-central Oklahoma [18]. Changes in nutrient concentration from fall to winter were comparable to those found by others [32]. Nutrient removal in harvested biomass was comparable to those found by others for a single-cut, after-frost harvest system [16, 18, 30, 31].

Unlike other findings indicating higher biomass yield for giant miscanthus than switchgrass [33], poor establishment combined with adverse soil and environmental conditions contributed to low biomass yields for giant miscanthus in this study. It has been reported that giant miscanthus response to precipitation is better than that of switchgrass [33]. This study site had sandy soils and received low precipitation and registered high temperatures during the establishment year. The low precipitation and high summer temperatures in 2008 (Table 1) led to low establishment success in giant miscanthus which affected plant density, growth and yield in subsequent production years. High biomass yields in weeping lovegrass may be related to its ability to rapidly establish and develop a thick canopy. The average biomass yield of $21 \mathrm{Mg} \mathrm{ha}^{-1}$ was higher than 7.9 $\mathrm{Mg} \mathrm{ha}^{-1}$ reported elsewhere for a single-cut, after-frost harvest system in northern Oklahoma [13, 14]. During the year of transplanting, rapid establishment appeared to give it an edge in resource use against weeds. A challenge with use of weeping lovegrass, however, was its susceptibility to harvest damage. It was observed that harvesting weeping lovegrass with the flail harvester partially uprooted these plants. Despite previous research showing that weeping lovegrass does well on sandy soils [34], the damage observed with mechanical harvesting may have been compounded by growing of these grasses on the sandy loam soil, where ability of roots to anchor the plant was lessened. Declines in biomass yields of weeping lovegrass from 2009 to 2010 likely resulted from compounding effects of mechanical damage, winter damage, and reduced rainfall. Harvesting weeping lovegrass after frost may have contributed to reduced yield in the second season as shown by other findings where harvesting after mid-fall was reported to predisposes the grass to winter damaged and reduced yield the following season [35].

Kleingrass produced relatively high biomass yields in the single-cut, after-frost harvest system despite its adaptation to multiple defoliations. Kleingrass has been shown to produce more than $6.0 \mathrm{Mg} \mathrm{DM} \mathrm{ha}^{-1}$ year $^{-1}$ in multiple harvest forage systems in Texas [15]. Early flowering and maturity of kleingrass could enhance nutrient remobilization to underground organs, but may limit growth and biomass yields relative to other perennial grasses. A concern with kleingrass like that with weeping lovegrass was that harvesting of this densely tillered grass during the first year contributed to reduced productivity of the stands during the second year. Weeping lovegrass, switchgrass, and kleingrass grew more as bunchgrasses, with a distinct base from which tillers arose, unlike in weeping lovegrass and kleingrass, lack of harvest damage in switchgrass during the first year may have been due to a combination of better rooting depth and an open rather than a closed cluster of tillers that made harvesting easier and less likely to disturb the rooting system. Despite being considered a noxious weed, Johnsongrass may have potential for use as a bioenergy crop. Johnsongrass competes strongly with crops. In one study, Johnsongrass height, relative growth rate, and unit leaf area was 3-fold, 1.5-fold and 4-fold higher, respectively than that of cotton [36]. With a 10 -fold greater root biomass and larger leaf area after 8 weeks of growth, Johnsongrass showed potential for greater resource use efficiency than cotton [36]. These qualities indicate a potential for Johnsongrass to use scarce resources efficiently for biomass production. In this study, Johnsongrass spread laterally with rhizomes and produced tillers in the inter-row spaces throughout the growing season, but senescenced earlier and experienced more lodging than the other grasses. Biomass produced in this study was lower than $9.7 \mathrm{Mg} \mathrm{ha}^{-1}$ year $^{-1}$ biomass yield obtained under a three-cut per year forage production in Mississippi [37]. The concentrations of $\mathrm{P}$ and $\mathrm{K}$ in the grasses were comparable to those found elsewhere [38]. Early onset of senescence may be positive for energy production, as the harvested material will have lower nutrient levels at harvest 
as shown for $\mathrm{P}$ and $\mathrm{K}$ in this study. However, early senescence also may have contributed to the increased lodging of Johnsongrass by the time of winter harvest.

The high nutrient concentrations early in the season for all species were attributed to predominance of young vegetative tissues. In late summer months, changing plant morphology with increased proportion of older tissue, reduced plant-nutrient demand and possible dilution due to increased biomass from rapid vegetative growth may explain reduced tissue element concentrations. Decreased mineral concentrations from fall to winter may be attributed to remobilization of nutrients from aboveground to belowground tissue during senescence. Similar scenarios has been widely reported by other researchers who found significant reduction in tissue element concentrations as harvest is delayed from fall to winter months [18, 19, 22, 36].

Low biomass nutrient concentration in 2010 especially for kleingrass and Johnsongrass which showed relatively early senescence was likely a result of a 1-month delayed harvest in 2010 compared to 2009 . The delay may have led to nutrient leaching as reported previously for $\mathrm{K}$ [39]. The relatively high nutrient concentration in giant reed compared to other species during most of the season was possibly due to its botanical characteristics. Unlike all the other species, giant reed is a C-3 grass, a group that lacks bundle sheath cells as found in C-4 grasses, thus, allowing for larger mesophyll cells in C-3 plants [40, 41] and may potentially increase cytoplasmic content including mineral elements. High level of nutrients in giant reed is not surprising as previous studies [21, 42, 43] have shown that $\mathrm{C}-3$ grasses have higher mineral elements than $\mathrm{C}-4$ grasses.

\section{Conclusions}

Giant reed, switchgrass, weeping lovegrass, and kleingrass may have potential for biomass production under the climatic conditions prevalent in the southern Great Plains. On this sandy soil, harvesting weeping lovegrass and kleingrass in winter for 2 years after establishment, caused reduced yields in the third year. Establishment of giant miscanthus on the sandy soil in this study was problematic and more evaluation is required before its true potential as a bioenergy crop in semi-arid environments like southern Oklahoma is known. Giant reed, a C-3 species, appeared to be a strong alternative to switchgrass, the leading perennial C-4 grass candidate for biomass energy production. However, its higher nutrient removal rates under annual harvesting of this grass would increase fertilization requirements over time. Therefore, based on these results, it appears that switchgrass may be the best suited perennial grass for the southern Great Plains due to its relatively high biomass yield and relatively low nutrient removal compared to the other species evaluated. Future research on giant reed should aim at high yields and reduced nutrient removal through increased leaf retention and increased remobilization of nutrients at senescence.

Open Access This article is distributed under the terms of the Creative Commons Attribution Noncommercial License which permits any noncommercial use, distribution, and reproduction in any medium, provided the original author(s) and source are credited.

\section{References}

1. McLaughlin SB, Kszos LA (2005) Development of switchgrass (Panicum virgatum) as a bioenergy feedstock in the United States. Biomass Bioenergy 28:515-535

2. Lewandowski I, Scurlock JMO, Lindvall E, Christou M (2003) The development and current status of perennial rhizomatous grasses as energy crops in the US and Europe. Biomass Bioenergy $25: 335-361$

3. Cassida KA, Muir JP, Hussey MA, Read JC, Venuto BC, Ocumpaugh WR (2005) Biomass yield and stand characteristics of switchgrass in south central U.S. environments. Crop Sci 45:673-681

4. Parrish DJ, Fike JH, Bransby DI, Samson R (2008) Establishing and managing switchgrass as an energy crop. Forage and Grazinglands. doi:10.1094/FG-2008-0220-01-RV

5. Muir JP, Sanderson MA, Ocumpaugh WR, Jones RM, Reed RL (2001) Biomass production of 'Alamo' switchgrass in response to nitrogen, phosphorus, and row spacing. Agron J 93:896-901

6. Sanderson MA, Read JC, Reed RL (1999) Harvest management of switchgrass for biomass feedstock and forage production. Agron J 91:5-10

7. Vogel KP, Breida JJ, Walter DT, Buxton DR (2002) Switchgrass biomass production in the Midwest USA: harvest and nitrogen management. Agron J 94:413-420

8. Mitchell R, Vogel KP, Sarath G (2008) Managing and enhancing switchgrass as a bioenergy feedstock. Biofuels, Bioproducts and Biorefining-Biofpr 2:530-539

9. Heaton EA, Dohleman FG, Long SP (2008) Meeting US biofuel goals with less land: the potential of Miscanthus. Glob Chang Biol 14:1-15

10. Angelinia LG, Ceccarini L, Bonarib E (2005) Biomass yield and energy balance of giant reed (Arundo donax L.) cropped in central Italy as related to different management practices. Eur J Agron 22:375-389

11. Mantineo M, D'Agosta GM, Copani V, Patane C, Cosentino SL (2009) Biomass yield and energy balance of three perennial crops for energy use in the semi-arid Mediterrenean environment. Field Crop Res 114:204-213

12. Knoll JE, Anderson WF, Strickland TC, Hubbard RK, Malik R (2011) Low-input production of biomass from perennial grasses in the Coastal Plain of Georgia, USA. Bioenergy Research. doi:10.1007/s12155-011-9122-x

13. Haque M, Epplin FM, Taliaferro CM (2009) Nitrogen and harvest frequency effect on yield and cost for four perennial grasses. Agron J 101:1463-1469

14. Aravindhakshan SC, Epplin FM, Taliaferro CM (2011) Switchgrass, bermudagrass, flaccidgrass and lovegrass biomass yield response to nitrogen for single and double harvest. Biomass Bioenergy 35:308-319 
15. Sanderson MA, Voigt P, Jones RM (1999) Yield and quality of warmseason grasses in central Texas. J Range Manage 52:145-150

16. Reynolds JH, Walker CL, Kirchner MJ (2000) Nitrogen removal in switchgrass biomass under two harvest systems. Biomass Bioenergy 19:281-286

17. Propheter JL, Staggenborg SA (2010) Performance of annual and perennial biofuel crops: nutrient removal during the first 2 years. Agron J 102:798-805

18. Guretzky JA, Biermacher JT, Cook BJ, Kering MK, Mosali J (2011) Switchgrass for forage and bioenergy: harvest and nitrogen rate effects on biomass yield and composition. Plant Soil 339:69-81

19. Adler PR, Sanderson MA, Boateng AA, Weimer PJ, Jung HG (2006) Biomass yield and biofuel quality of switchgrass harvested in fall or spring. Agron J 98:1518-1525

20. Sanderson MA, Martin NP, Adler P (2007) Biomass, energy, and industrial uses of forages. In: Barnes RF et al (eds) Forages. The science of grassland agriculture. Vol II, 6th edn. Blackwell Publishing, Ames, Iowa, pp 635-647

21. Monti A, Di Virgilio N, Venturi G (2008) Mineral composition and ash content of six major energy crops. Biomass Bioenergy 32:216-223

22. Heaton EA, Dohleman FG, Long SP (2009) Seasonal nitrogen dynamics of Miscanthus $x$ giganteus and Panicum virgatum. Global Change Biology Bioenergy 1:297-307

23. Lierop WV (1990) Soil pH and lime requirement determination. In: Westerman RL (ed) Soil testing and plant analysis, 3rd edn. ASA-CSSA-SSSA, Madison, Wisconsin, pp 73-126

24. Nelson DW, Sommers LE (1982) Total carbon, organic carbon and organic matter. In: Page AL (ed) Methods of Soil Analysis. Part 2-Chemical and Microbiological Properties, 2nd edn. ASACSSA-SSSA, Madison, Wisconsin

25. Fixen PE, Grove JH (1990) Testing soils for phosphorus. In: Westerman RL (ed) Soil testing and plant analysis, 3rd edn. ASACSSA-SSSA, Madison, Wisconsin, pp 141-180

26. Haby VA, Russelle MP, Skogley EO (1990) Testing soils for potassium, calcium, and magnesium. In: Westerman RL (ed) Soil testing and plant analysis, 3rd edn. ASA-CSSA-SSSA, Madison, Wisconsin, pp 181-228

27. Littell RC, Milliken GA, Stroup WW, Wolfinger RD (1996) SAS system for mixed models. SAS Institute, Cary, NC, pp 87-134

28. Speck O, Spatz H (2004) Damped oscillation of the giant reed Arundo donax (Poaceae). Am J Bot 91:789-796

29. Rossa B, Tuffers AV, Von Willert DJ (1998) Arundo donax L. (Poaceae) - $\mathrm{a}_{3}$ species with unusually high photosynthetic capacity. Bot Acta 111:216-221

30. Fike JH, Parrish DJ, Wolf DD, Balasko JA, Green JT Jr, Rasnake M, Reynolds JH (2006) Long-term yield potential of switchgrass-for-biofuel systems. Biomass Bioenergy 30:198206

31. Lemus R, Parris DJ, Wolf DD (2009) Nutrient uptake by 'Alamo' switchgrass used as an energy crop. Bioenergy Research 2:37-50

32. Yang JD, Worley E, Wang MY, DE Lahner S, Saha M, Udvardi M (2009) Natural variation for nutrient use and remobilization efficiencies in switchgrass. Bioenergy Research 4:257-266

33. Heaton E, Voight T, Long SP (2004) A quantitative review comparing the yields of two candidate C-4 perennial biomass crops in relation to nitrogen, temperature and water. Biomass Bioenergy 2:21-30

34. Shoop, M.C., and E.H. Mcllvain. 1970. Growth patterns of weeping lovegrass and how they relate to management. In: Dalrymple, R.L. (ed.). Proceedings of the First 29 Weeping Lovegrass Symposium, April 28-29. The Samuel Roberts Noble Foundation, Ardmore, Oklahoma. p. 1-9. website:http://www. noble.org/ag/Forage/LovegrassSymposium.pdf

35. Dalrymple RL1970. Weeping lovegrass establishment and management of the first year stands. In:Dalrymple, R.L. (ed.). Proceedings of the First29 Weeping Lovegrass Symposium, April 28-29. The Samuel Roberts Noble Foundation, Ardmore, Oklahoma. p. 21-28. Website: http://www.noble.org/ag/Forage/ LovegrassSymposium.pdf

36. Holt JS, Orcutt DR (1991) Functional relationships of growth and competitiveness in perennial weeds and cotton (Gossypiumhirsutum L.). Weed Sci 39:575-584

37. McLaughlin MR, Fairbrother TE, Rowe DE (2004) Nutrient uptake in warm-season perennial grasses in a swine effluent spray field. Agron J 96:484-493

38. Lewandowski I, Kicherer A (1997) Combustion quality of biomass: practical relevance and experiment to modify the biomass quality of Miscanthus $x$ giganteus. Eur J Agron 6:163-177

39. Fixen PE (2007) Potential biofuels influence on nutrient use and removal in the U.S. Better Crops 91:12-14

40. Akin DE, Burdick D (1975) Percentage of tissue types in tropical and temperate grass leaf blades and degradation of tissue by rumen microorganism. Crop Sci 15:661-668

41. Buxton DR, Redfearn DD (1997) Plant limitation to fiber digestion and utilization. J Nutr 127:814-818

42. Long MIE, Ndyanabo WK, Marshall B, Thornton DD (1969) Nutritive value of grasses in Ankole and the Queen National Park, Uganda IV-mineral content. Tropical Agric 46:201

43. Reid RL, Jung GA, Cox-Ganser JM, Rybeck BF, Townsend EC (1990) Comparative utilization of warm-and cool-season forages by cattle, sheep and goats. J Anim Sci 68:2986-2994 